http://jmscr.igmpublication.org/home/

ISSN (e)-2347-176x ISSN (p) 2455-0450

crossref DOI: https://dx.doi.org/10.18535/jmscr/v8i12.27

Journal Of Medical Science And Clinical Research

\title{
Study of Prevalence of Dyslipidemia in Shimla
}

\author{
Authors \\ Dr Meenu Aggarwal ${ }^{1}$, Dr Narinder Mahajan ${ }^{2}$ \\ ${ }^{1}$ Resident Medical Officer Indian Institute of Advanced Study Shimla \\ ${ }^{2}$ Associate Professor, Department of Community Medicine, Indira Gandhi Medical College Shimla
}

\begin{abstract}
Background and Objectives: Dyslipidemia is a major risk factor for cardiovascular disease. It includes high levels of triglyceride (TG), total cholesterol (T-cholestrol), low density lipoprotein cholesterol (LDL-c) and low level of high density lipoprotein cholesterol $(H D L-c)$. Therefore it is important to know the lipid levels of community for early intervention and prevention of cardiovascular disease. The present study investigated the lipid levels of urban population of Shimla

Methods: A descriptive cross sectional study was conducted in a health centre at Shimla. 132 samples were tested in the individuals above 18 years of age. Blood samples following overnight fast was collected for determination of serum TG, T-cholestrol, LDL-c and HDL-c. According to the criteria of the National Cholestrol Education Program- Adult treatment Panel III (NCEP-ATP III), Dyslipidemia was classified into (a) Hyperlipidemia-TC $>200 \mathrm{mg} / \mathrm{dl}, \quad T G>150 \mathrm{mg} / \mathrm{dl}$, (b)Hypercholestrolemia $T C>200 \mathrm{mg} / \mathrm{dl}$ (c) Hypertriglyceridemia $T G>150 \mathrm{mg} / \mathrm{dl}$, (d) Atherogenic dyslipidemia $T G>150, L D L C>165$

Results: A total number of 132 adult individuals were enrolled of which 80 (61\%) and $52(39 \%)$ were male and female respectively. Study found 32\% hyperlipidemia, 30\% atherogenic dyslipidemia,8\% hypercholesterolemia and 30\% hypertriglyceridemia. 35.60\% had low HDL. 7.58\% had high LDL. BMI was higher among females as compared to males. $(p=<0.01)$

Conclusion: Prevalence of atherogenic dyslipidemia and hyperlipidemia are common and female dyslipidemic patients are susceptible to develop higher BMI. Which calls for urgent lifestyle intervention strategies to prevent and manage this.

Keywords: Dyslipidemia, Hypercholestrolemia, hypertriglyceridemia.
\end{abstract}

\section{Introduction}

Elevated levels of cholestrol is an important risk factor in cardiovascular disease. Increased consumption of fast food and decrease in physical activity are associated with adverse changes in the lipid profile. Economic prosperity has also led to prevalence of lifestyle related diseases. The atherosclerotic $\mathrm{CHD}$ has been reported as a leading cause of death and disability not only in countries with high socioeconomic development but also in developing countries. Pathogenic character of cholesterol is determined not only by its blood levels but also its distribution in lipoproteins. Low density lipoprotein (LDL) carried cholestrol is potentially pathogenic and high density lipoprotein (HDL) carried one is index of a shielding role of lipoproteins against atherosclerosis. ${ }^{(3)}$ The imbalance status of one or more types of lipoproteins in blood is known as dyslipidemia $^{(4)}$ and considered as an established independent major risk factor for CHD. It might even be a prerequisite occurring before other 
major risk factors come into play. Low concentration of HDL-C and high concentration of TGs have been implicated as possible independent predictors of $\mathrm{CHD}^{(5)}$ and combinations of these two conditions have been defined as atherogenic dyslipidemia (AD) ${ }^{(6)}$.

The atherosclerotic CHD has been reported as a leading cause of death and disability not only in countries with a high socio-economic development but also in developing countries ${ }^{(14)}$. Because of the largest population group, the Asians are suffering from the major part of the global burden of CHD. In addition, since Asians have many different ethnic groups of population who may have different lipid profiles ${ }^{(15)}$. The INTERHEART investigators reported a higher prevalence of dyslipidemia among study participants living in five South Asian countries (India, Pakistan, Bangladesh, Sri Lanka and Nepal). Based on this scenario a specific assessment of the pattern of dyslipidemia is important to design and plan for health services need and preventive measures to reduce the mortality and morbidity rates.

Effective control of blood lipid levels reduced cardiovascular morbidity and mortality. In this context the present study was designed to determine lipid levels and prevalence of dyslipidemia in urban community of Shimla.

Objective of study was to determine the fasting lipid profile in the Shimla urban population with selected socio demographic factors such as age, sex, socio-economic status etc.

\section{Material and Methods}

The study was designed to assess the lipid levels in urban population of Shimla.

Study Design: Descriptive cross sectional study.

Study Area: Health centre at Indian Institute of Advanced Study Shimla.

Study Population: Adults $\geq 18$ years of age.

Study Tools: Interview schedule, anthropometry, fasting sugar, urea, creatinine, uric acid and lipid profile.
Sample Size: 132 Subjects.

\section{Laboratory, anthropometric and clinical data collection}

Face to face interview was conducted by using a pre-tested structured questionnaire to collect the data. Body mass index (BMI) was calculated from height and weight measured by a height weight scale following standard operating procedure (SOP). $5 \mathrm{ml}$ fasting venous blood was collected between 8AM - 9AM.

According to the criteria of National Cholestrol Education Program-Adult Treatment Panel 111(NCEP-ATP111), dyslipidemia was diagnosed and classified into four phenotyped, (a) Hyperlipidemia: TC>200mg/dl, TG>150mg/dl, (b) Hypercholestrolimia: TC>200 $\mathrm{mg} / \mathrm{dl}$, (c) Hypertriglyceridemia: $\quad \mathrm{TG}>150 \quad \mathrm{mg} / \mathrm{dl}, \quad$ (d) Atherogenic-dyslipidemia: $\quad \mathrm{TG}>150 \mathrm{mg} / \mathrm{dl}$, LDLC>165 mg/dl.(7.16) Underweight, Normal weight, Overweight and Obesity were determined according to World Health Organization guideline. Fasting blood glucose levels >6.1 $\mathrm{mmol} / \mathrm{L}$ was referred to diabetic.

\section{Statistical Analysis}

t- test was performed to see the gender variation among dyslipidemic subjects. $\mathrm{A}^{\prime} \mathrm{p}^{\prime}$ value $=0.05$ was considered as statistically significant.

\section{Results}

Of 132 participants, $61 \%(n=80)$ were male and rest of them were female. The proportion of dyslipidemia was higher among the 46 to 76 years age group $39.4 \%(n=52)$ compared to 36 to 45 years $29.5 \%(n=39)$ and 18 to 35 years $31.1 \%$ $(n=41)$ age groups.The highest proportion of dyslipidemia was reported among the overweight and obese $40.9 \%(n=54)$.

The pattern of dyslipidemia is summarized in Table 2. Out of 132 participants, $38 \%(n=50)$ had hyperlipidemia $(\mathrm{TC} \geq 200 \mathrm{mg} / \mathrm{dl}, \mathrm{TG} \geq 150 \mathrm{mg} / \mathrm{dl})$ $38 \% \quad(\mathrm{n}=50)$ had atherogenic dyslipidemia $(\mathrm{TG} \geq 150 \mathrm{mg} / \mathrm{dl}, \mathrm{LDLC} \geq 165 \mathrm{mg} / \mathrm{dl}), 7.6 \% \quad(\mathrm{n}=10)$ had hypercholesterolemia (TC $\geq 200 \mathrm{mg} / \mathrm{dl})$ and $30 \%(n=40)$ had hypertriglyceridemia $(\mathrm{TG} \geq 150)$. 
Table 1. Baseline characteristics of the study participants

\begin{tabular}{|c|c|c|c|}
\hline \multicolumn{2}{|l|}{ Characteristics } & \multirow{2}{*}{$\begin{array}{c}\text { Frequency } \\
(\mathrm{n})\end{array}$} & \multirow{2}{*}{$\begin{array}{c}\text { Percentage }(\%) \\
61\end{array}$} \\
\hline Gender & Male & & \\
\hline & Female & 52 & 39 \\
\hline \multirow[t]{3}{*}{ Age Group } & $\begin{array}{l}18 \text { to } 35 \\
\text { years }\end{array}$ & 41 & 31 \\
\hline & $\begin{array}{l}36 \text { to } 45 \\
\text { years }\end{array}$ & 39 & 30 \\
\hline & $\begin{array}{l}46 \text { to } 76 \\
\text { years }\end{array}$ & 52 & 39 \\
\hline \multirow[t]{3}{*}{ Education } & $\begin{array}{l}\text { Under } \\
\text { Matric }\end{array}$ & 52 & 39 \\
\hline & Graduate & 30 & 23 \\
\hline & $\begin{array}{l}\text { Post } \\
\text { Graduate }\end{array}$ & 50 & 38 \\
\hline \multirow[t]{3}{*}{$\begin{array}{l}\text { Socioeconomic } \\
\text { Status }\end{array}$} & $\begin{array}{l}\text { Low } \\
\text { Income }\end{array}$ & 43 & 33 \\
\hline & $\begin{array}{l}\text { Middle } \\
\text { Income }\end{array}$ & 44 & 33 \\
\hline & $\begin{array}{l}\text { High } \\
\text { Income }\end{array}$ & 45 & 34 \\
\hline \multirow[t]{3}{*}{ BMI Status } & $\begin{array}{l}\text { Under } \\
\text { Weight }\end{array}$ & 7 & 5 \\
\hline & $\begin{array}{l}\text { Normal } \\
\text { Weight }\end{array}$ & 71 & 53.7 \\
\hline & $\begin{array}{l}\text { Over } \\
\text { weight } \\
\text { and Obese }\end{array}$ & 54 & 40.9 \\
\hline \multirow{2}{*}{$\begin{array}{l}\text { Glycemic } \\
\text { Status }\end{array}$} & Diabetic & 13 & 9.8 \\
\hline & $\begin{array}{l}\text { Non- } \\
\text { Diabetic }\end{array}$ & 119 & 90 \\
\hline
\end{tabular}

Table 2. Pattern of dyslipidemia

\begin{tabular}{|l|c|c|}
\hline Type of Dyslipidemia & Frequency(n) & Percentage \\
\hline Hyperlipidemia & 42 & 32 \\
\hline Atherogenic & 40 & 30 \\
\hline Hypercholestrolemia & 10 & 8 \\
\hline Hypertriglyceridemia & 40 & 30 \\
\hline
\end{tabular}

For lipid profile and FBS, a significant difference was found among different gender groups. Table 3 shows that among the dyslipidemic subjects, FBS, TC, LDL-C and TG of female were significantly higher than the male patient.

FBS was higher among hyperlipidemia group compared to hyper cholestrolemia group

Table 3. Comparison of different parameters according to gender among dyslipidemic subjects

\begin{tabular}{|l|c|c|}
\hline \multirow{2}{*}{ Parameter } & \multicolumn{2}{|c|}{ Gender } \\
\cline { 2 - 3 } & Male & Female \\
\hline BMI & 25.157 & 25.048 \\
\hline TC & 168.71 & 170 \\
\hline HDL-C & 45.82 & 45.22 \\
\hline LDL-C & 96 & 98.24 \\
\hline TG & 140.34 & 142.58 \\
\hline FBS & 86.96 & 92.86 \\
\hline
\end{tabular}

Table 4. Comparison of FBS among the study subjects with different dyslipidemia types

\begin{tabular}{|l|c|}
\hline Dyslipidemia Type & FBS \\
\hline HL $(\mathrm{n}=49)$ & 6 \\
\hline HC $(\mathrm{n}=14)$ & 1 \\
\hline HT $(\mathrm{n}=35)$ & 6 \\
\hline AD $(\mathrm{n}=35)$ & 6 \\
\hline Status of BMI & Glycemic Status \\
\hline UW $(\mathrm{n}=7)$ & 87.7 \\
\hline NW $(\mathrm{n}=71)$ & 86.51 \\
\hline OW and OB $(\mathrm{n}=54)$ & 95.33 \\
\hline
\end{tabular}

Comparison of Glycemic status among the participants with different BMI status shows that the serum mean level of FBS was significantly higher among the overweight and obese group compared to the normal weight as well as underweight group.

\section{Discussion}

This study was carried out at the outpatient department (OPD) of Health Centre at Shimla to assess the pattern and factors associated with dyslipidemia among adult population. Our results found that the proportion of dyslipidemia was a bit higher among the 46 to 76 years age group in comparison to the other groups.

In terms of income we have found that majority of the dyslipidemic patients were middle or higher income group. It might be due to less physical activity.

In our study most common type of dyslipidemia was hyperlipidemia (32.0\%). The level of TC and TG were found higher among female compared to male.

Our study findings show that increase in BMI was significantly associated with the FBS level.

\section{Conclusion}

This study concludes that Hyperlipidemia and Atherogenic dyslipidemia are more common types of dyslipidemia among adult population in Shimla. Female dyslipidemic patients are more susceptible to develop higher FBS, TC, LDL-C, and TG. Hyperlipidemic adults have higher chance of increased level of FBS as compared to the hypercholestrolemic group. We would like to 
recommend urban women to maintain their FBS and Lipid profile within normal range for preventon of dyslipidemia.

\section{Acknowledgements}

We are thankful to the study participants for their valuable time and patience during the whole study period.

\section{References}

1. Rukhsana Rabeya,Mohammad Hayatun Nabi, Ariful Bari Chowdhary. Epidemiology of Dyslipidemia among Adult Population of Bangladesh. Rom. J. Diabetes, Nutr, Metab Dis.26(2)99-106. 2019.

2. World Health Organization. The atlas of heart disease and stroke/Judith Mackay and George Mensah; with Shanthi Mendis and KURT Greenland. Geneva: World Health Organization 2004. http;/www.who.int/iris/handle/10665/43007 (accessed on 12th October 2018).

3. Natarajan P, Ray KK, Cannon CP. High density lipoprotein and coronary heart disease. J AM Coll Cardiol 55(13):12831299,2010.

4. Smith S, Lall AM. A study on lipid profile levels of diabetics and non diabetics among Naini region of Allahabad, India. Turkish J Biochem 33(4):138-141.2008.

5. Amarenco P, Labreuche J, Toubol PJ. High density lipoprotein-cholestrol and risk of stroke and carotid atherosclerosis. A systematic review. Atherosclerosis 196(2) 489-496,2008.

6. Fruchart JC, Sacks F, Hermans MP, Assmann G, Brown WV, Ceska R et al. The Residual Risk Reduction Initiative: a call to action to reduce residual vascular risk in patients with dyslipidemia. Am J Cardiol 102(IOS)1K-34K.2008.

7. Bhalodkar NC, Blum S, Rana T, Bhalodkar A, Kiitchappa R, Kim KS, et al. Comparison of levels of large and small high density lipoprotein cholesterol in Asian Indian men compared with Caucasian men in the Framingham offspring study. Am J Cardiol 94:1561-1563, 2004.

8. Neaton JD, Wentworth D. Serum cholesterol, blood pressure, cigarette smoking, and death from coronary heart disease. Overall findings and differences by age for 316,099 white men. Multiple risk factor intervention trial research group. Arch Intern Med 152 (I):56-64, 1992.

9. Yusuf S, Reddy S, ounpuu S, Anand S. Global burden of disease, part 1: general considerations, the epidemiologic transition, risk factors and impact of urbanization. Circulation 104(22):2746-2753,2001.

10. Farzadfar F, Finucane MM, Danaei G. Global Burden of Metabolic Risk Factors for Chronic Diseases Collaborating Group (Cholestrol) National, regional and global trends in serum total cholesterol since 1980: systemic analysis of health examination surveys and epidemiological studies with 321 country -years and 3.0 million participants. Lancet 377(9765):578-586, 2011.

11. Labreuche J, Touboul PJ, Amarenco P. Plasma triglyceride levels and risk of stroke and carotid atherosclerosis: A systemic review of the epidemiological studies. Atherosclerosis 203(2): 331-345,2009.

12. Karthikeyan G, Teo KK, Islam S, McQueen MJ, Pais $\mathrm{P}$, Wang $\mathrm{X}$ et al. Lipid profile, plasma apolipoproteins, and risk of a first myocardial infarction among Asians: An analysis from the INTERHEART study.J Am Coll Cardiol53(3):244-253.2009.

13. Bakesiima R, Byakika-Kibwika $P$, Tumwine JK et al. Dyslipidemias in women using hormonal contraceptives: a cross sectional study in Mulago Hospital Family Planning Clinic , Kampala, Uganda. BMJ Open 8 (10):eo22338,2018.

14. World Health Organization. Global status report on non communicable diseases 2010, Geneva. Accessed at: 
https://www.who.int/nmh/publications/ncd - report-full-en.pdf

15. Heng DM. Lee J. Chew SK. Tan BY. Hughes K. Chia KS. Incidence of Isschemic Heart Disease and Stroke in Chinese, Malays, and Indians in Singapore: Singapore Cardiovascular Cohort Study. Ann Accad Med Singapore29(2): 231236,2000.

16. Reddy KS. Cardiovascular disease in non Western countries. N Engl J Med 350(24):2438-2440.2004

17. Li Qi, Xianbin D, Wenge T, Qin Li, Deqiang, M.Yulin W. Prevalence and Risk Factors Associated with Dyslipidemia in Chongqing. China. Int. J.Environ. Res. Public Health 12(10): 13455-13465,2015.

18. Bener A, Mohammad AG, Ismail AN, Zirie M, Abdullatef WK, AI-Hamaq AQ. Gender and age- related differences in patients with the metabolic syndrome in a highly endogenous population. Bosn J Basic Med Sci 10(3):210-217,2010.

19. Li Y,ZhaoL, Yu D, Ding G. The prevalence and risk factors of dyslipidemia in different diabetic progression stages among middle aged and elderly populations in China. PLoS One 13(10):e0205709, 2011.

20. Cai L, Zhang L, Liu A, Li S, Wang P, Prevalence, awareness, treatment, and control of dyslipidemia among adults in Beijing, China. J Atheroscler Thromb19(2):159-168,2011.

21. Wang S, Xn L, Jonas JB, You QS, Wang YX, Yang H. Prevalence and associated factors of dyslipidemia in the adult Chinese population. PLoS One 6(3),2011.
22. Sharma U, Kishore J. Garg A, Anand T, Chakraborty M, Lali P, Dyslipidemia and associated risk factors in a resettlement colony of Delhi. J Clin Lipidol 7(6):653660, 2013.

23. Gupta R, Ravinder S. Rao, Misra A, Samin K. Sharma. Recent trends in epidemiology of dyslipidemias in India. Indian Heart Journal 69(3):382-392,2017.

24. Bayram F, Kocer D, Gundogan K, Kaya A, Demir O, Coskun $\mathrm{R}$ et al. Prevalence of dyslipidemia and associated risk factors in Turkish adults. J Clin Lipidol 8(2):206216,2014.

25. O'Brien T. Nguyen TT, Zimmerman BR, Hyperlipidemia and diabetes mellitus. Mayo Clin Proc 73(10):969-976,1998.

26. Misra A and Shrivastava U. Obesity and Dyslipidemia in South Asians. Nutrients 5(7):2708-2733, 2013.

27. Gebel Erika. A matter of the sexes:the differences between men and women with diabetes. Diabetes Forecast 64(10):46-49, 2011.

28. Hillier TA, Pedula KL. Characteristics of an Adult Population with Newly Diagnosed Type 2 Diabetes. The relation of obesity and age of onset. Diabetes care 24(9): 15221527, 2001. 